\title{
Perspectives on ICT applications in medical education
}

Prof. J. U. Weerasinghe BDS, MS, PhD

Professor in Oral \& Maxillofacial Surgery, Faculty of Dental Sciences, University of Peradeniya, Sri Lanka Visiting Professor, Post Graduate Institute of Medicine, University of Colombo, Sri Lanka Executive Editor, Sri Lanka Journal of Bio-medical Informatics

E-Mail address: juw@pdn.ac.lk

Sri Lanka Journal of Bio-Medical Informatics 2012;3(3):63-64

doi: http://dx.doi.org/10.4038/sljbmi.v3i3.4926

Out of the estimated world population of seven billion, about one third ( 2.2 billion) have become internet users by 2012 which comprises of $45 \%$ of Asians, $22 \%$ of Europeans and $11 \%$ of North Americans ${ }^{(1)}$. During the past five years, internet users in the developing world have overtaken those in developed countries ${ }^{(2)}$.

For most of us living in this digital age, seeking information at home or work has become part of our routine. The type of digital information requested, depends on the requirements of the receiver, researchers, clinicians and students who are becoming increasingly empowered with knowledge obtained through digital means.

With computing technology becoming integrated into most of the appliances and devices and the development of networking, internet facilities and mobile technology, new concepts such as social networking and cloud computing have emerged. Some of these technological tools such as Facebook, Twitter, blogs, RSS aggregators, mobile devices, open access archives and repositories have helped to make information seeking much more comprehensive and convenient ${ }^{(3)}$.

Information seekers visit search engines such as Yahoo and Google before proceeding to specific websites. Internet has been used as a supplemental resource to obtain health information ${ }^{(4)}$. In addition to storage tools numerous online resources such as websites, blogs and Learning Management Systems (LMS) are available for the use of health practitioners and students.

The lead article in this issue explores the possibility of implementation of LMS courses as continuing medical education activities for physicians ${ }^{(5)}$. Two articles in this issue deals with studies carried out on ICT literacy of undergraduate students ${ }^{(6,7)}$. Another article discusses how problem based learning (PBL) courses were introduced to a group of undergraduates encouraging them to seek information from printed and electronic resources ${ }^{(8)}$. One other use of internet resources is interaction between trainees and trainers. The last article presents how a blog was used for the interaction between a postgraduate trainee and supervisors ${ }^{(9)}$.

In conclusion this issue intends to present the current perspectives of the usage of information sought at various levels in the filed of medical education that has helped to improve the knowledge of the medical community comprised of researchers, clinicians and students.

\section{References}

1. World Internet Users and Population Stats - Internet World Stats. Available from http://www.internetworldstats.com/stats.htm. Accessed on 24-11-2012 
2. The exponential growth of the internet. Available from http://www.21stcenturychallenges.org. Accessed on 24.11.2012.

3. Xuemei Ge. Information seeking behaviour in the digital age. College and Research Libraries. 2010; 71:435-455.

4. Higgins O, Sixsmith J, Barry MM, Domegan C. A literature review on health information-seeking behaviour on the web: a health consumer and health professional perspective. Stockholm: CDC;11. 2011. http://dx.doi.org/doi 10.2900/5788.

5. De Silva N, Kulasekera GU. Learner evaluation of an online continuing medical education course for general practitioners. Sri Lanka Journal of Bio-Medical Informatics. 2012; 3(3): 65-74 doi: http://dx.doi.org/10.4038/sljbmi.v3i3.4470

6. Wijerathne HK, Walpola VR, Mahamithawa AMP, Bandara DGDPDS, Wijerathne BTB. Newly entered medical students' views on an Information Communication Technology course. Sri Lanka Journal of Bio-Medical Informatics. 2012; 3(3): 75-81 doi: http://dx.doi.org/10.4038/sljbmi.v3i3.2254

7. Yapa YMMM, Dilan MMNS, Karunaratne WCD, Widisinghe CC, Hewapathirana R. et al. Computer Literacy and Attitudes towards eLearning among Sri Lankan Medical Students Sri Lanka Journal of Bio-Medical Informatics. 2012; 2(3): 82-96 doi: http://dx.doi.org/10.4038/sljbmi.v2i3.3719

8. Dissanayaka TD, Marambe KN, Liyanage E. Physiotherapy students' perception on problem based learning. Sri Lanka Journal of Bio-Medical Informatics 2012; 3(3): 97 100

doi: http://dx.doi.org/10.4038/sljbmi.v3i3.4787

9. Sheriff MR, Weerasinghe JU, Ponnamperuma G. Use of a blog as a tracking tool for student-supervisor interaction in a Biomedical Informatics course: Future portfolios. Sri Lanka Journal of Bio-Medical Informatics 2012; 3(3): 100-5

doi: http://dx.doi.org/10.4038/sljbmi.v3i3.3779 